\title{
核沸騰起動におけるループヒートパイプ蒸発器の気液相分布挙動
}

\author{
西川原 理仁*1，上田 洋佑*2，柳田 秀記 ${ }^{* 1}$
}

\section{Liquid-vapor phase displacement in the evaporator of a loop heat pipe at the start-up involving nucleate boiling}

\author{
Masahito NISHIKAWARA ${ }^{* 1}$, Yosuke UEDA ${ }^{* 2}$ and Hideki YANADA*1 \\ ${ }^{*} 1,{ }^{* 2}$ Department of Mechanical Engineering, Toyohashi University of Technology \\ 1-1 Hibarigaoka, Tenpaku-cho, Toyohashi-shi, Aichi 441-8580, Japan
}

Received: 18 December 2017; Revised: 22 January 2018; Accepted: 30 March 2018

\begin{abstract}
Liquid-vapor phase distribution and displacement in the capillary evaporator of loop heat pipes (LHP) is a key phenomenon to understand the steady state and transient behavior. However, the phenomenon has not been investigated sufficiently thus far. In this study, the liquid-vapor phase behavior on the contact surface between the wick and evaporator case at start-up is observed with a transparent evaporator case coated with an ITO heater. Visualization experiments are conducted during the LHP operation at $0.59-5.6 \mathrm{~W} / \mathrm{cm}^{2}$ of heat flux applied to the evaporator. Nucleate boiling and temperature drop on the evaporator wall by superheating are observed when the grooves and vapor line inlet are initially saturated with liquid. Right after nucleate boiling, the whole surface of the wick is dried instantaneously, then liquid in the compensation chamber (CC) wets the wick. In the imbibition, two regimes where the liquid filling rate into the wick is different are found. At a high heat flux, vapor pockets are observed at the contact surface between the wick and evaporator case even in a steady state. Thermo-fluid simulations which take into account disordered porous media and effective thermal conductivity of the wick obtained from directly solving a heat conduction equation in reconstructed porous media using X-ray computed tomography are conducted. The simulation results of evaporator wall temperature and saturation at the contact surface agree with the observation at $5.6 \mathrm{~W} / \mathrm{cm}^{2}$ of heat flux. Both simulation and observation results show residual liquid phase along the three-phase contact lines within the case, wick, and grooves.
\end{abstract}

Keywords : Capillary evaporator, Drainage, Effective thermal conductivity, Imbibition, Loop heat pipe, Nucleate boiling incipience, Pore network model, Vapor pocket, Visualization

\section{1. 緒言}

ループヒートパイプ（LHP） は蒸発と凝縮による潜熱と多孔体内で働く毛細管力を利用した熱輸送デバイスで ある. 1990 年台後半より宇宙機における熱制御に利用され始め，近年では電子機器の冷却，排熱利用など様々な 産業への応用が期待されている.

LHP 起動特性は，初期の蒸発器内の気液分布によって異なることが報告されている．蒸発器温度の才一バーシ ユートが起きた場合, 温度制御対象機器の許容温度を一時的に超える事態になりうるため, 起動特性の理解と内 部挙動の解明は安全性の高い設計に必要である。初期の蒸発器内の気液分布はグルーブおよび補償室 (CC) が液 で満たされているか，二相状態であるかの 4 つのパターンに分類されている．特にグルーブ内が液で満たされて いるときに核沸騰による蒸発の開始および過熱による温度のオーバーシュートが報告されている（Maidanik et al., 1995, Ku, 2016). しかし可視化によって蒸発器内の起動特性は調べられていないため, 著者らはこれまでに蒸発

No.17-00576 [DOI:10.1299/transjsme.17-00576], J-STAGE Advance Publication date : 10 April, 2018

${ }^{* 1}$ 正員, 豊橋技術科学大学 大学院工学研究科（下441-8580 愛知県豊橋市天伯町雲雀ヶ丘 1-1）

*2 学生員, 豊橋技術科学大学 大学院工学研究科

E-mail of corresponding author: nishikawara@me.tut.ac.jp 
器ケースにガラス管を用いた可視化 LHP を製作し，初期気液分布の影響を調査した. 蒸気管入口, グルーブ, $\mathrm{CC}$ それぞれが気液二相状態か液で満たされている状態かでパターン分けを行い観察したところ，グルーブおよ び蒸気管入口が夜で満たされている場合に核沸騰起動および過熱オーバーシュートを観察した (Nishikawara et al., 2017).

本研究では, 核沸騰起動時の熱流動挙動に焦点を当て, 蒸発器内の気液界面挙動および温度応答, さらにそれ らが負荷される熱流束によってどのように変化するのかを可視化蒸発器によって調べた．さらに定常状態におけ る蒸発器特性を予測するためポアネットワークモデル (PNM) を用いた蒸発器解析を行い, 実験結果と比較した. それらの結果について報告する.

\section{2. 実験方法}

\section{$2 \cdot 1$ 実験装置}

これまで行われた蒸発器の可視化 (Liao and Zhao, 2000, Xu et al., 2014, Mottet et al., 2015, Odagiri et al., 2017, Hatakenaka and Okamoto, 2011, Launay and Mekni, 2010) はウィック断面すなわちグルーブ軸方向に対して垂直面の 観察であったが，本研究ではウィックと蒸発器ケースの接触面およびグルーブ軸方向に対して平行面の観察を行 う.なぜなら，2 次元性が保たれるような蒸発器の形状および境界条件においてはウィック断面のみの挙動を理 解すれば十分であるが, 実際の現象は 3 次元的であることがほとんどであるため, 接触面における挙動は蒸発器 性能を理解するうえで重要となるからである.

毛細管限界における蒸発器への熱流束が $20 \mathrm{~W} / \mathrm{cm}^{2}$ となるように可視化 LHP を設計した. 構築した可視化 LHP を図 1 に, 代表寸法を表 1 に示寸. 本研究の LHP 可視化実験装置は蒸発器内部の観察を行うにあたり, 蒸発器ケ 一ス材料は透明な石英ガラス管， ウィックの材料には石英ガラス多孔体を用いた．ウィックの細孔半径は水銀圧 入法により計測し, ピーク值が $3.2 \mu \mathrm{m}$, 空隙率は $37 \%$ である. ウィックとガラス管は再焼結により結合させた. まずクリアランスのある状態でウィックをガラス管に挿入し，再焼結させる．再焼結工程でガラス管は縮径し， クリアランスがなくなる.製作後の蒸発器の外径計測により, クリアランスが埋まっていることを確認しており, ウィックとガラス管は十分に密着した状態である.さらに蒸発器のシール性はバブルポイント試験により検証し, 細孔径に対応寸る毛細管圧まで駆動できることを確認した（Nishikawara et al., 2017).

蒸発器ガラス管外側のグルーブ長さ $45 \mathrm{~mm}$ の領域に透明導電膜である酸化インジウムスズ（ITO）を成膜し， 通電加熱で熱流束を負荷した. コンデンサはコールドプレートに設置し排熱を行った. チラーにより冷却したエ チレングリコールを循環させコールドプレートを冷却した. 蒸発器以外は断熱材により覆い, 周囲への熱損失を 十分小さくした．蒸発器ガラス管表面は素線径 $0.127 \mathrm{~mm}$ の $\mathrm{T}$ 型熱電対によって温度を計測した. 計測位置は蒸

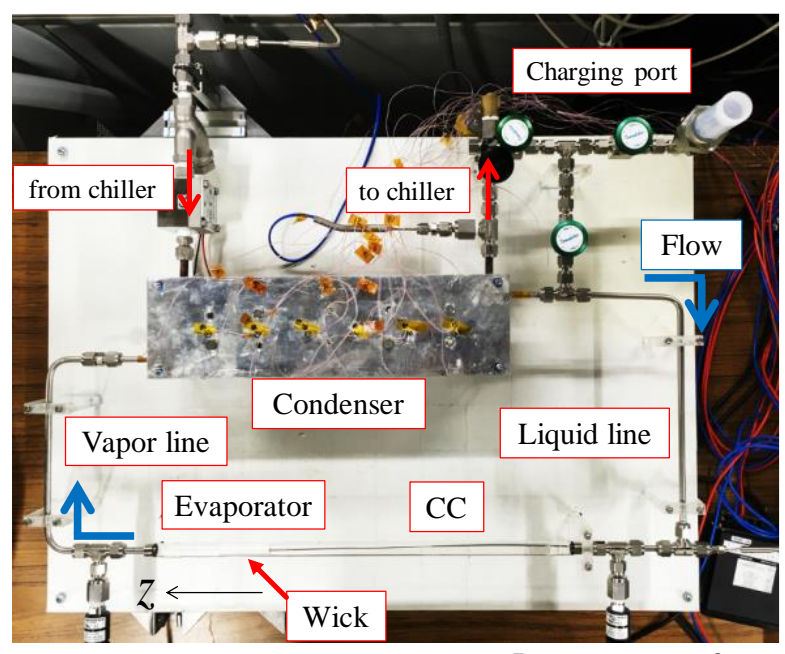

Pressure sensor 1
Pressure sensor 2
Table 1 The LHP dimensions. O.D. is outer diameter.

\begin{tabular}{lll}
\hline \hline & Length[mm] & O.D.[mm] \\
\hline \hline Wick & 50 & 12 \\
\hline Evaporator & 50 & 15 \\
\hline CC & 300 & 15 \\
\hline VL & 440 & 6.4 \\
\hline Condenser & 950 & 6.4 \\
\hline LL & 510 & 6.4 \\
\hline \hline
\end{tabular}

Fig. 1 Overview of experimental apparatus. 
発器の中央部分 $15 \mathrm{~mm}$ 幅の領域に均等に 3 点, 軸方向に平行になるようにし配置し, 取付け方法は治具により熱 電対線を空中に固定し観察面裏側のガラス管表面に押し付けて接触させた. さらに, 蒸発器前後の圧力を計測し 飽和温度を算出した。蒸発器内の観察はマイクロレンズを装着した一眼レフカメラにより行った. フレームレー トは $30 \mathrm{fps}, 1$ ピクセルは $20 \mu \mathrm{m}$ である.

\section{$2 \cdot 2$ 実験条件}

予備実験により取得した可視化 LHP の最低起動熱流束 $0.59 \mathrm{~W} / \mathrm{cm}^{2}$, 最大熱流束 $5.6 \mathrm{~W} / \mathrm{cm}^{2}$, 中間の $2.4 \mathrm{~W} / \mathrm{cm}^{2}$ で 核沸騰起動を調べた. 最大熱流束はヒータの耐熱温度 $20{ }^{\circ} \mathrm{C}$ により定まる限界值である. 作動流体にはアセトン を用いた．作動流体封入後，十分な時間放置しても内圧は変化しておらずループの気密性が十分であることを確 認した．初期気液分布は，実験前に蒸発器を冷却したり実験装置を傾けたりすることにより調整し，グルーブお

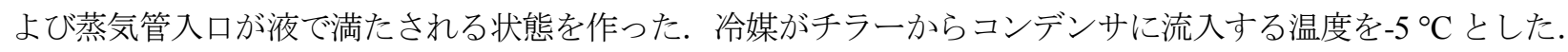

\section{3. 解析方法}

\section{$3 \cdot 1$ 計算概略}

計算領域を図 2 に示す．円筒蒸発器構造の一周期分であり, 簡単化のためウィック底部を引き延ばし直方体形 状とした. 大きさが, $3.8 \times 4.0 \times 45 \mathrm{~mm}(L x \times L y \times L z)$ であり, 石英ケース, 石英ウィック，グルーブから成る. 各寸法は実験での蒸発器形状・寸法と合わせ, グルーブ高さが $1 \mathrm{~mm}$, ケース厚さが $1.5 \mathrm{~mm}$, ウィックがケース と接触している面積（図 2 の Contact surface）は $L x \times L z$ に対して面積比 $46 \%$ あるる. グルーブおよびウィックの $\mathrm{CC}$ 側境界には実験で計測された飽和温度および圧力を均一に与えた. 多孔体内流動解析には次節に示す PNM を 用いて計算した。

ウィック内のエネルギー保存としては, 熱伝導と対流を考慮した方程式を考え, 蒸発器ケースの熱伝導方程式 も同時に解く.

$$
\begin{aligned}
& c_{p} \dot{\boldsymbol{m}} \cdot \nabla T=k_{\text {eff }} \nabla^{2} T \\
& k_{\text {case }} \nabla^{2} T=0
\end{aligned}
$$

ここで， $c_{p}$ は気体または液体の定圧比熱， $\dot{\boldsymbol{m}}$ は質量流束ベクトル， $T$ は温度， $k_{\text {case }}$ は蒸発器ケースの熱伝導率， $k_{\text {eff }}$ は気相または液相の多孔体の実効熱伝導率であり, 算出方法は 3.3 節で示寸.

ウィック内の相分布は液単相と気液二相状態の 2 つがある. 蒸発器への熱負荷が低い場合, ウィックは液で満 たされている. 熱負荷が高い場合, 加熱面付近の液相の過熱度が高くなり, 所定の過熱度に達するとウィック内 に残存寸る気泡の核生成によって気相領域が発生し図 2 のようにウィック内に気液界面が形成される. 本モデル では, 二相状態へ遷移する過熱度 $\Delta T_{\text {sup }}$ は, 細孔半径 $r$ と同じ半径の気泡が熱平衡を保つことができる過熱度とし た（日本機械学会, 2014）.

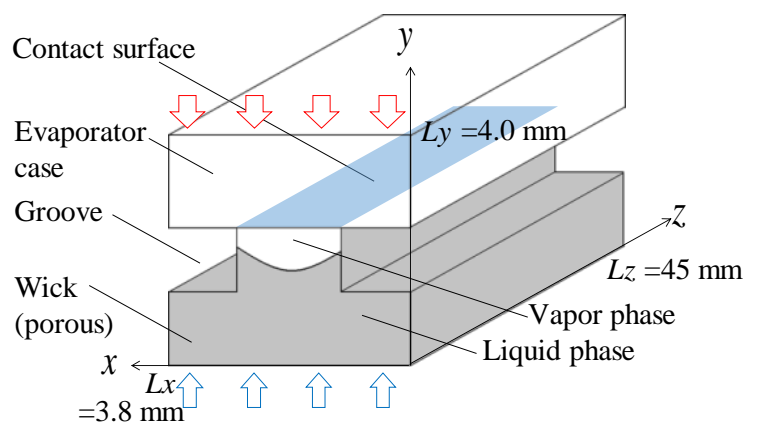

Fig. 2 Computational domain.

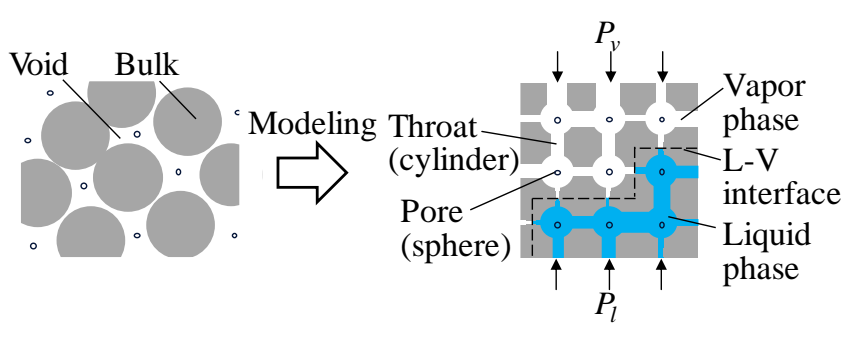

Fig. 3 Schematic of pore network model. 


$$
T-T_{\text {sat }}(P)>\Delta T_{\text {sup }}=\frac{2 \sigma T_{\text {sat }}}{\rho_{v} r H_{f g}}
$$

ここで $T$ はウィック温度， $T_{\text {sat }}$ は局所の飽和温度であり，局所の圧力より算出される． $\sigma$ は表面張力， $\rho_{v}$ は蒸気密 度, $H_{f g}$ は蒸発潜熱である. 気液二相状態での界面位置は, 界面前後での気相と液相の圧力差が毛細管圧力と釣り 合うように界面位置を計算する．格子間隔は $0.2 \mathrm{~mm}$ とし，全格子点数は 8 万点となった．また本解析では，界 面熱伝達係数は $4.9 \times 10^{4} \mathrm{~W} / \mathrm{m}^{2} \mathrm{~K}$ ， ウィックと $\mathrm{CC}$ 間の熱伝達率は $100 \mathrm{~W} / \mathrm{m}^{2} \mathrm{~K}$ ， ウィックとケースの接触部の熱伝 達率は $4.0 \times 10^{4} \mathrm{~W} / \mathrm{m}^{2} \mathrm{~K}$ とし, ウィックが気相領域の時のグルーブとの境界は断熱とした. 解析の詳細は文献を参 照されたい（西川原，長野，2015, Nishikawara et al., 2015). 本解析モデルは過去に LHP の実験結果との比較によ って妥当性が検証・確認されたものである（Nishikawara et al., 2015）.

\section{$3 \cdot 2$ ポアネットワークモデル (PNM)}

PNM は，多孔体の空隙構造をPore と Throatに分解し Pore を交点としたネットワークによりモデル化する. 空 孔率, 細孔半径, 浸透率などのマクロな值は, 空隙形状すなわち, 本モデルでは Pore 半径, Throat 半径, Throat 長さによって再現できる. 本モデルでは正方格子を用いてポアネットワークを構築した (図 3). 局所の最大毛細 管圧力 $P_{c a p}$ は, Throat 半径 $r_{t h}$ を用いて記述される.

$$
P_{c a p}=\frac{2 \sigma \cos \theta}{r_{t h}}
$$

ここで, $\theta$ は接触角である. アセトンと石英の接触角は, 液滴法によって石英平板上のアセトン液滴の画像を取 得し $\theta / 2$ 法によって算出した。接触角は $12.5^{\circ}$ であった. Throat 半径は，使用した石英多孔体の細孔径分布を考慮 している. 水銀圧入法によって計測した細孔径分布を図 4 に示寸. 図 4 の分布となるように Throat 半径をランダ ムに格子上に配置する. Throat を流れる流量は両端の Pore の圧力差に比例し, Pore における質量保存を考えると 下記の圧力に関する方程式が成立する.

$$
\sum_{n=1}^{6} \frac{g_{i, n}}{v}\left(P_{i}-P_{n}\right)=0
$$

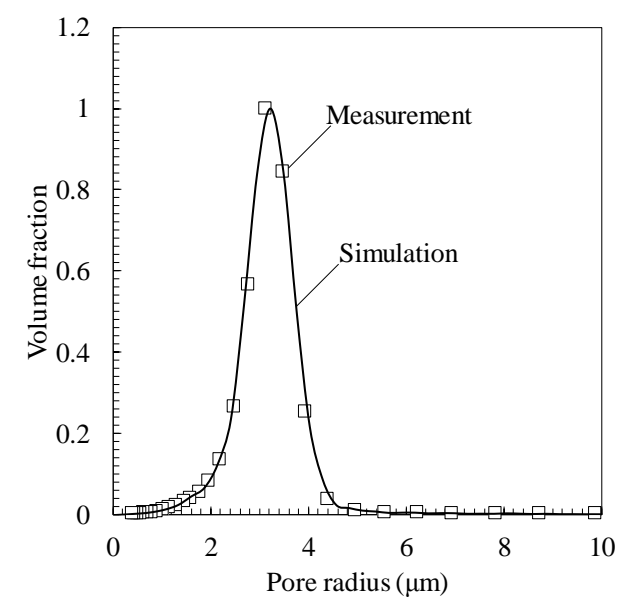

Fig. 4 Pore radius distribution measured by mercury intrusion technique. Vertical axis is normalized by the maximum value.

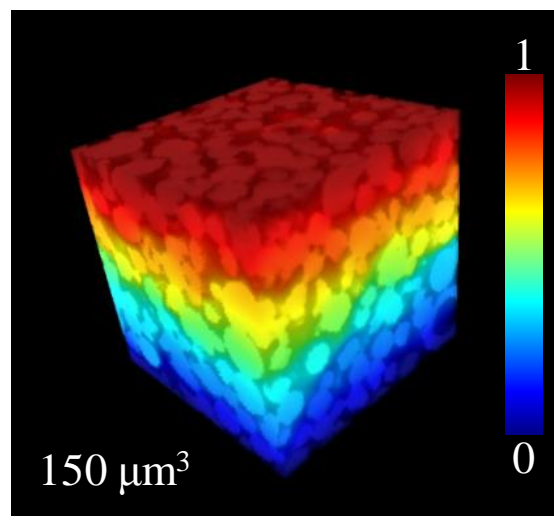

Fig. 5 Temperature distribution in cubic porous sample obtained by directly solving heat conduction equation. In color bar, 1 is the highest temperature and 0 is the lowest one. 
ここで， $g_{i, n}$ は Pore $i$ と $n$ 間の Throat における流動コンダクタンス, $v$ は気体または液体の動粘性係数である. $g_{i, n}$

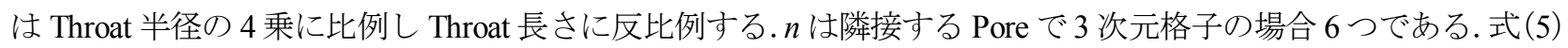
によってウィック内の圧力が求まり, 各 Throat における流量が求まる. また $g_{i, n}$ はウィックの浸透率が $1.6 \times 10^{-13} \mathrm{~m}^{2}$ となるようにフィッティングした.

\section{$3 \cdot 3$ 実効熱伝導率}

多孔体の実効熱伝導率は，その空隙構造に大きく依存し，各構造型によって実効熱伝導率の推定式が提案され ている（大島他，1979，根岸他，1985, Peterson and Fletcher, 1987，竹内，1999，Faghri, 2016, Chi, 1976，国井，1976， Alexander, 1972, Maxwell, 1954, Krupiczka, 1967, Bruggeman, 1935). 推定式は，固相と流体相の熱伝導率，多孔体の 空隙率によって実効熱伝導率を推定するが，金属多孔体と樹脂多孔体，高空隙率と低空隙率など，推定式に含ま れる各物理量の值が大きく変わった場合, 同じ構造型であっても推定值と計測值との差が大きくなることもあり, 推定式によって精度よく予測することは困難である. 文献（Krupiczka，1967）では実効熱伝導率と流体相の熱伝 導率の比が 1 40 までの範囲で提案された推定式と計測值の比較を行っているが, その差が $\pm 30 \%$ 程度の推定精度 に留まる. そこで本研究では高精度に実効熱伝導率を求めるため, X 線 CT を用いて多孔体構造を PC 上に再構築 して, 得られた 3 次元像に対して直接熱伝導方程式を解くことによって温度場を求め実効熱伝導率を算出する手 法を用いた．本手法によって使用する多孔体の幾何学形状を直接考慮することができ，また熱伝導のみを考慮し た実効熱伝導率を求めることができる.

X 線 CT には，ナノフォーカス CT スキャナ phoenix nanotom $\mathrm{m}$ を用いた. ボクセルサイズ $0.5 \mu \mathrm{m}$ で撮影した. 得られたグレースケール画像を二值化処理して多孔体の 3 次元像を取得した. 取得した多孔体は一辺 $150 \mu \mathrm{m} の$ 立方体である．立方体サンプルを用いて上面と下面に一定温度の境界条件を与えて熱伝導方程式を解いた．その ほかの側面は断熱条件を与えた。対流，放射の影響は無視した。空隙部分が液体で満たされている場合と気体で 満たされている場合で計算し，液相領域と気相領域の実効熱伝導率を求めた．固体部分には石英の熱伝導率 1.38 W/m·K（日本熱物性学会, 2008）を，空隙部分には液体もしくは気体の熱伝導率 $0.175 \mathrm{~W} / \mathrm{m} \cdot \mathrm{K}$ もくは $0.0126 \mathrm{~W} /$ $\mathrm{m} \cdot \mathrm{K}$ （THERMAL-FLUIDS CENTRAL, 2017）を与えた. 得られた温度場よりサンプルを通過する熱流束 $\dot{q}$ を求め フーリエの法則より実効熱伝導率 $k_{\text {eff }}$ 算出した.

$$
k_{\text {eff }}=-\frac{\dot{q}}{(\Delta T / L)}
$$

ここで $\Delta T$ は与えた上下面の温度差， $L$ はサンプル長さである. 温度場の解析結果を多孔体構造とともに図 5 に 示す．固相の分布によって温度分布も影響を受けてばらついていることが分かる．液相および気相の実効熱伝導 率の結果を表 2 に示寸. 空隙率で重みづけした単純な並列則, 直列則および粒子充てんの多孔体で提案されてい る推定式による值も示寸，並列則では解析結果に対して過大評価，直列則では過小評価となり，さらに各推定式

Table 2 Simulated and estimated effective thermal conductivity of a sintered quartz wick saturated with liquid or vapor, $k_{\text {eff } \_}$or $k_{\text {eff } \_} v$.

\begin{tabular}{lll}
\hline \hline Method & $k_{\text {eff } \_}[\mathrm{W} / \mathrm{m} \cdot \mathrm{K}]$ & $k_{\text {eff } \_}[\mathrm{W} / \mathrm{m} \cdot \mathrm{K}]$ \\
\hline \hline Simulation & 0.699 & 0.454 \\
\hline Parallel law & 0.924 & 0.865 \\
\hline Series law & 0.375 & 0.033 \\
\hline Chi, 1976 & 0.568 & 0.071 \\
\hline Kunii, 1976 & 0.533 & 0.161 \\
\hline Alexander, 1972 & 0.340 & 0.059 \\
\hline Maxwell, 1954 & 0.823 & 0.732 \\
\hline Krupiczka, 1967 & 1.119 & $\underline{0.430}$ \\
\hline Bruggemann, 1935 & $\underline{0.663}$ & 0.165 \\
\hline \hline
\end{tabular}


においても液相，気相の解析結果とどちらも一致するような結果にはなっていない．液相の実効熱伝導率におい ては Bruggemann, 気相においては Krupiczka の推定式による結果が解析結果との差が $5 \%$ ななり，比較的よく予 測できていることが分かった．また表 2 に示した $6 つ の$ 推定式と解析結果との差の平均は，液相の実効熱伝導率 では 30\%，気相では 61\%となり，特に気相における実効熱伝導率の推定は差が大きかった.

蒸発器の解析には表 2 の Simulation の実効熱伝導率を用いる.

\section{4. 結果と考察}

\section{$4 \cdot 1$ 実験結果}

全ての熱負荷条件において核沸騰起動が可視化によって観察された. 各熱流束における䒱発器壁面温度（3 点 の平均值）の時間履歴を図 6 に示寸. 熱流束が低くなるにつれ核沸騰開始までの時間が長くなり，0.59 W/ $\mathrm{cm}^{2}$ で は加熱開始から $300 \mathrm{~s}$ 後に核沸騰が観察された。 $0.59,2.4 \mathrm{~W} / \mathrm{cm}^{2}$ では核沸騰直後に温度の急下降（オーバーシュー

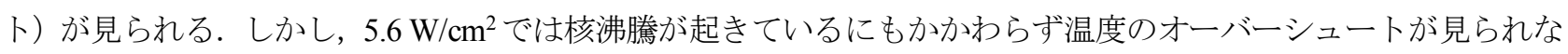
かった. 低熱流束での温度オーバーシュートはこれまで $0.3 \mathrm{~W} / \mathrm{cm}^{2}$ (Maydanik at al., 1995)， $0.2 \mathrm{~W} / \mathrm{cm}^{2}(\mathrm{Ku}, 2016)$, $0.02 \mathrm{~W} / \mathrm{cm}^{2}$ （Kaya et al., 1999）程度の熱流束で報告されているが，今回 $2.4 \mathrm{~W} / \mathrm{cm}^{2}$ 程度でも顕著になるということ が分かった。過熱度を蒸発器壁面温度と飽和温度との差で算出したところ, 最大過熱度はそれぞれ $30{ }^{\circ} \mathrm{C} \quad(0.59$ $\left.\mathrm{W} / \mathrm{cm}^{2}\right), 61^{\circ} \mathrm{C} \quad\left(2.4 \mathrm{~W} / \mathrm{cm}^{2}\right), 86^{\circ} \mathrm{C} \quad\left(5.6 \mathrm{~W} / \mathrm{cm}^{2}\right)$ であった。 また蒸発器の熱伝達率は, それぞれ $15,000 \mathrm{~W} / \mathrm{m}^{2} \mathrm{~K}$ $\left(2.4 \mathrm{~W} / \mathrm{cm}^{2}\right), 1,900 \mathrm{~W} / \mathrm{m}^{2} \mathrm{~K}\left(5.6 \mathrm{~W} / \mathrm{cm}^{2}\right)$ であった. 熱伝達率の算出においては, ガラスの熱抵抗は差し引いた. $0.59 \mathrm{~W} / \mathrm{cm}^{2}$ では熱伝達率が高く, 計測精度の問題で熱伝達率を算出できなかった.

$2.4 \mathrm{~W} / \mathrm{cm}^{2}$ における起動から定常状態への遷移の写真を図 7 に示寸. $0 \mathrm{~s}$ は熱負荷開始時間であり, 蒸発器内は 全て液で満たされている. 熱負荷開始から $22 \mathrm{~s}$ 後にウィック表面全体が白くなっており, 核沸騰によりウィック 表面全体が瞬間的に乾いている様子が観察できる. その後 $100 \mathrm{~s}$ 程度かけて一度乾いた領域に CC 内の液が浸透し ていく様子が観察された．定常状態においては，ウィックはすべて液で満たされた状態となった．以前の実験

（Nishikawara et al., 2017）でも同様な核沸騰現象が観察されており，再現性のある結果が得られた.

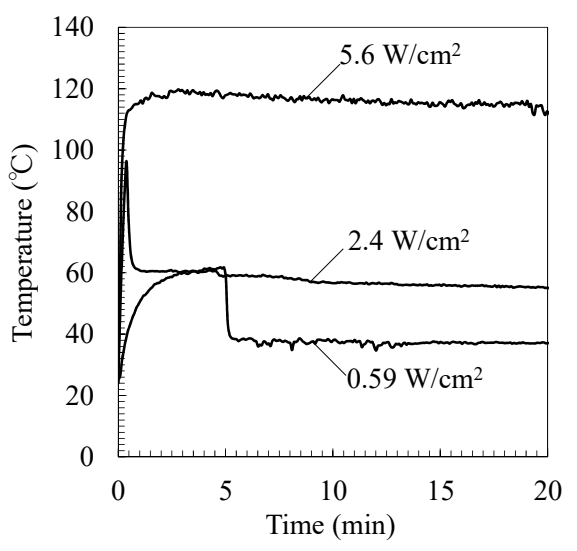

Fig. 6 Temperature history of the evaporator wall at Fig. 7 different applied heat fluxes.

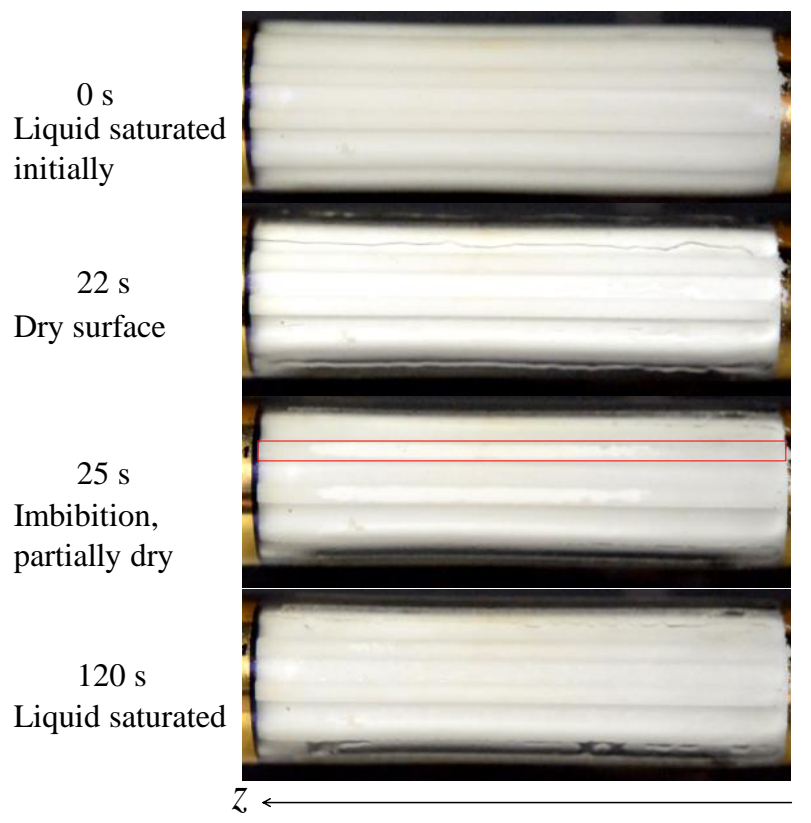

Time sequence of observation of transparent evaporator at $2.4 \mathrm{~W} / \mathrm{cm}^{2}$ of heat flux. $0 \mathrm{~s}$ is start of heating, $22 \mathrm{~s}$ is right after nucleate boiling, and $120 \mathrm{~s}$ is in a steady-state. 
ケースとウィックとの接触面における乾きおよび吸水挙動を詳細にみるため, 図 7 の赤線で囲った接触領域の 画像を ImageJ を使用し二值化処理して気相領域と液相領域を判別した. 二值化処理では, 液で満たされた初期状 態の画像との差をとることにより液相, 気相の各領域を判定した. 図 8 に各熱負荷における時間毎の接触面にお ける二值化画像を示す. 画像の白が気相領域, 黒が液相領域を示している. $0 \mathrm{~s}$ は核沸騰直前の時間と定義した. どの熱負荷においても核沸騰によって乾きあがった後, ウィックの左右端が先に濡れており, その後中央部も濡 れていく吸水挙動であることが分かった. $0.59 \mathrm{~W} / \mathrm{cm}^{2}$ と $2.4 \mathrm{~W} / \mathrm{cm}^{2}$ では定常状態においては, 全て液で満たされ た状態となったが, $5.6 \mathrm{~W} / \mathrm{cm}^{2}$ では図 $8 \mathrm{c}$ の $32.40 \mathrm{~s}$ に示すように, 定常状態においても接触面の中央部がドライア ウトしていることが観察された. ウィックの一部のドライアウトによって $5.6 \mathrm{~W} / \mathrm{cm}^{2}$ で蒸発器の熱伝達率が低く なったと考えられる. ドライアウトは軸方向の中央部分であるので, 軸方向の分布をつけないような苲発器形状 設計によって高熱流束下における熱伝達率の向上が期待できると考えられる.

今回の実験における多孔体への吸水挙動（Imbibition）では, 気液界面形状は枝状に広がった状態（Viscous Fingering）や非対称な状態（Capillary Fingering）ではなく，終始比較的滑らかな状態（Compact Displacement）で ある (図 9)。これは従来の多孔体内非混合二相流, 相置換に関寸る研究 (Cieplak and Robbins, 1988, Holtzman and Segre, 2015, Trojer, et al., 2015）によると，液体の接触角が $12.5^{\circ}$ と比較的小さいことが原因である（図 9 の接触角 は本研究と異なり疎水性流体で定義されており, 参考文献での $\theta=120^{\circ}$ は, 本研究に合わせると $\theta=60^{\circ}$ となるの で注意)。しかし, 従来の研究では熱, 相変化の影響は考慮されていない. そのため, 本研究のように蒸発を伴う 場合の多孔体内気液界面形状において，どの程度熱の影響があるかは明らかにはなっていない，接触面における 気液界面形状および相分布は, 蒸発器の熱伝達特性に大きく影響を与えうるため, 蒸発器の高性能化において重 要であり今後の課題である.

接触面における吸水挙動を定量的に議論寸るため, 二值化画像より飽和度を算出した. 飽和度は多孔体の濡れ ている割合を表し，二值化画像の黒の面積割合より算出した。 各熱負荷での接触面における飽和度の時間履歴を 図 10 に示寸. 濡れた状態 $(S=1)$ から, 核沸騰によってウィックが乾きあがり $(S=0)$, その後ウィックが吸水し $S$ の值が 1 に向かって増加している様子が分かる. 乾きあがった後は, 熱負荷が高い方が速く吸水している. 0.59 $\mathrm{W} / \mathrm{cm}^{2}$ では $5.4 \mathrm{~s}$ 後に $S$ が 0.95 以上, $2.4 \mathrm{~W} / \mathrm{cm}^{2}$ でもグラフには示されていないが, $26.8 \mathrm{~s}$ 後に 0.95 以上になって いる. それに対し， $5.6 \mathrm{~W} / \mathrm{cm}^{2}$ では定常状態においても $S$ は 1 に近づくことなく, 0.63 で一定になった.

また, 吸水速度を表す $S$ の傾きはある時刻を境に急変化している. 吸水速度は, 乾きあがり直後に急激に増加 乙 (図 10 の A), その後吸水速度が低くなる（図 10 の B) ことが分かる. このような挙動は熱流束 $0.59 \mathrm{~W} / \mathrm{cm}^{2}$ と $2.4 \mathrm{~W} / \mathrm{cm}^{2}$ (図 10 の挿入図) で見られる. $5.6 \mathrm{~W} / \mathrm{cm}^{2}$ では飽和度が一定になるまでの時間が短く, 今回の撮影速 度では吸水速度の変化の様子が捉えられなかった. $0.59 \mathrm{~W} / \mathrm{cm}^{2}$ と $2.4 \mathrm{~W} / \mathrm{cm}^{2}$ の結果に対し, 領域 A の飽和度を時 間の二次関数, 領域 $\mathrm{B}$ を $0.59 \mathrm{~W} / \mathrm{cm}^{2}$ では一次関数, $2.4 \mathrm{~W} / \mathrm{cm}^{2}$ では二次関数で表し, その微分係数より吸水速度 を算出した. 領域 $\mathrm{A}$ と B の平均の $\mathrm{R}^{2}$ （決定係数）が最大となる時間を A から B に遷移する時間とした. 結果を 図 11 に示寸. 領域 $\mathrm{A}$ では吸水速度が増加しており, 領域 B では吸水速度は $0.59 \mathrm{~W} / \mathrm{cm}^{2}$ では一定, $2.4 \mathrm{~W} / \mathrm{cm}^{2}$ では 低下している. 領域 A から B に遷移寸る時間は, $0.59 \mathrm{~W} / \mathrm{cm}^{2}$ では $2.30 \mathrm{~s}, 2.4 \mathrm{~W} / \mathrm{cm}^{2}$ では $0.43 \mathrm{~s}$ であった. 図 $8 \mathrm{a}, \mathrm{b}$ に示される遷移時の相分布より，それぞれの時間では接触面の中央部に乾いた領域がまだ多く残された状態であ ることが分かる. 寸なわち遷移点以降の領域 B では接触面中央部一吸水が行われる. 中央部は端部より高温であ ることが温度計測結果より分かっている. 高温の中央部では, 吸水とともに吸水された液が蒸発する. その分液 相の侵入が遅くなると考えられる. 寸なわち蒸発の影響の有無によって二つの領域 A，B が形成され，影響のあ る領域 Bでは吸水速度が小さくなると考えられる。このことからも多孔体一の吸水挙動には, 蒸発の影響が表れ ていることが分かる．ウィック温度によって蒸発のない場合（A）とある場合（B）の二つの吸水挙動があるとい うことは解析モデルを構築する上で重要な知見である. また今回は核沸騰によって多孔体が二相状態へ遷移して いるが, 初期状態でグルーブに気相領域が存在する場合は接触面より徐々に気相領域が拡大していく(Mottet et al., 2015)。この時, 気液界面形状および相分布は排水挙動（Drainage）によって決まるため, 蒸発器の熱流動現象を 理解するには, 吸水挙動のみならず排水挙動も重要となる. 
(a)

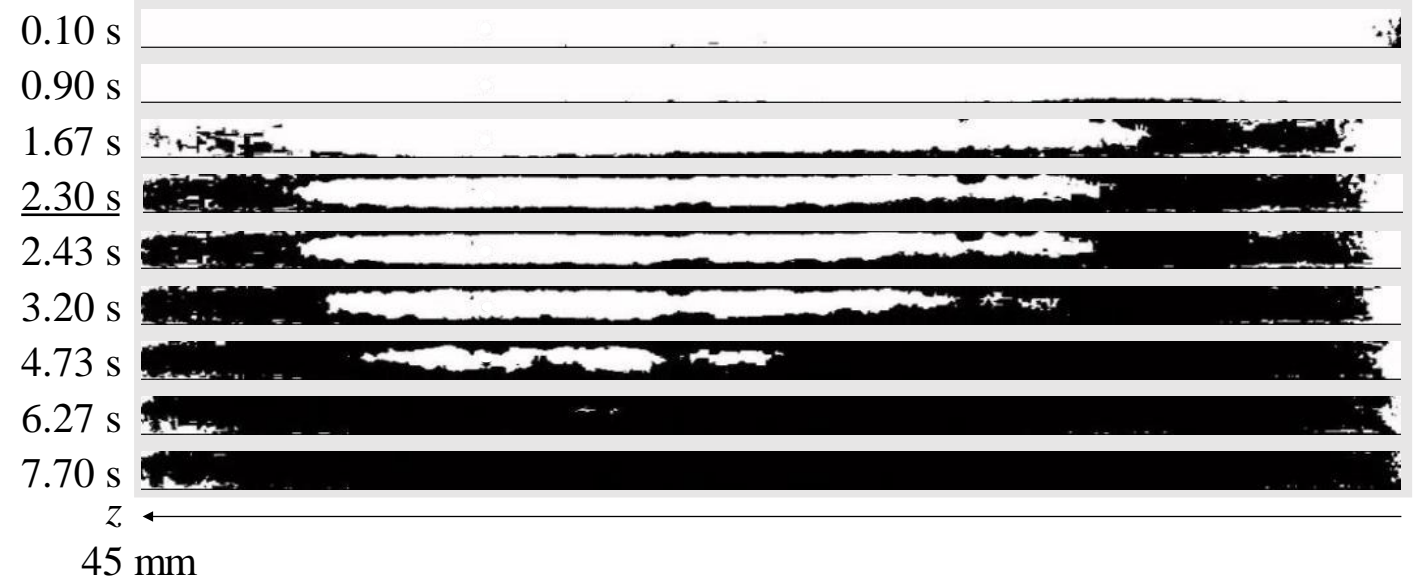

(b)

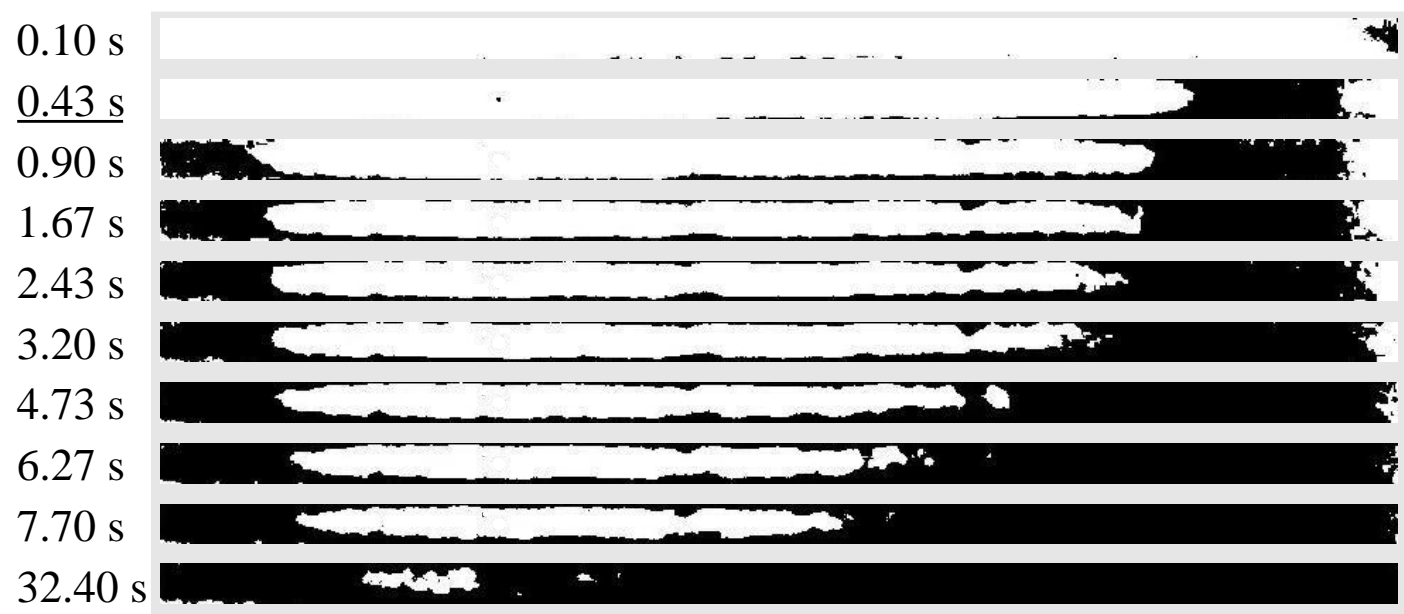

(c)

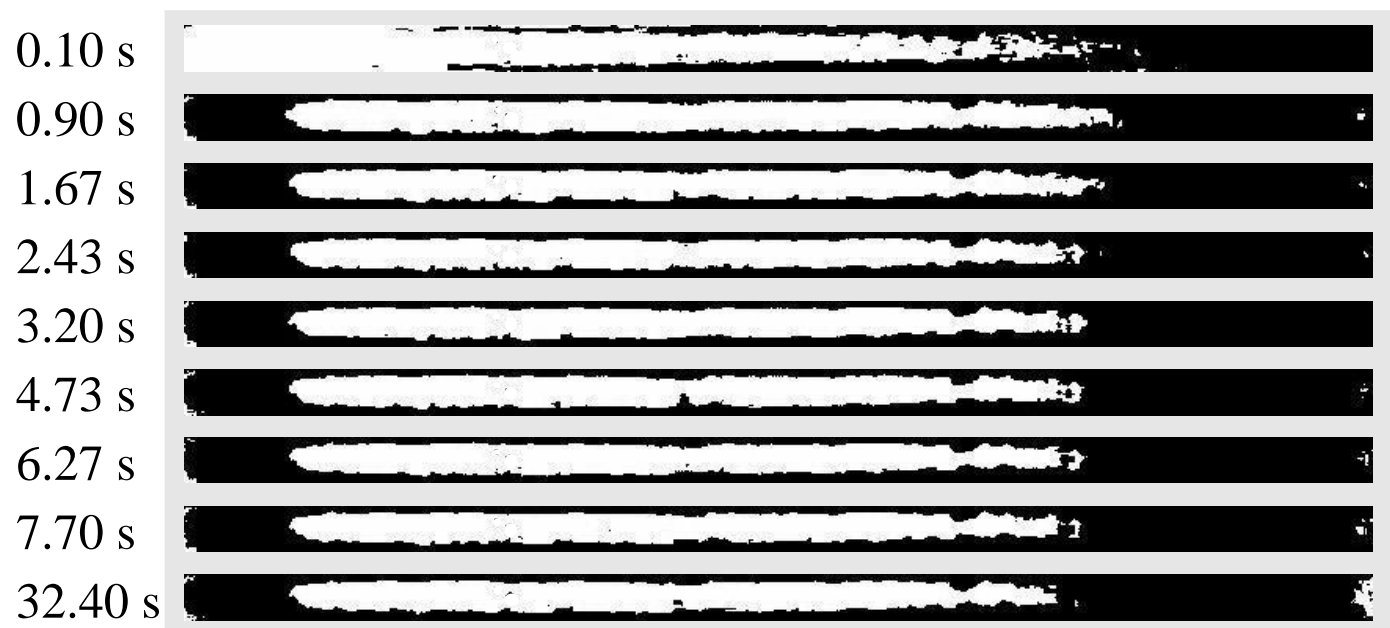

Fig. 8 Time sequence of binarized images of the contact surface between the wick and evaporator case. $0 \mathrm{~s}$ is right after nucleate boiling. White is vapor phase and black is liquid phase. (a) is $0.59 \mathrm{~W} / \mathrm{cm}^{2}$ of heat flux, (b) is $2.4 \mathrm{~W} / \mathrm{cm}^{2}$, and (c) is 5.6 $\mathrm{W} / \mathrm{cm}^{2}$. 


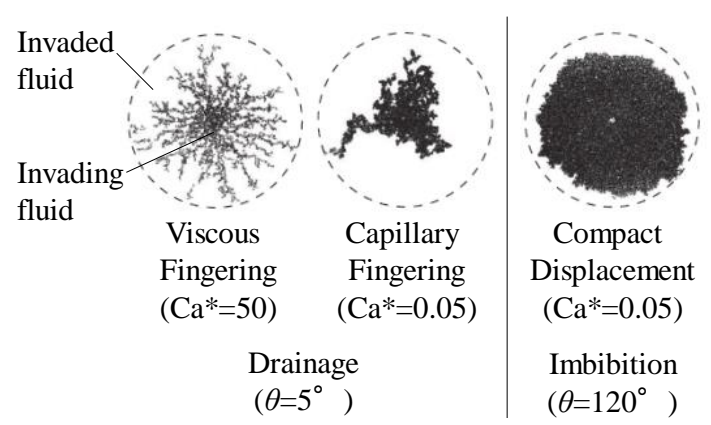

Fig. 9 Visual phase diagram of the fluid-fluid-displacement morphologies obtained during air injection (dark) into the center of a porous medium filled with a mixture of water and glycerol (clear), as a function of the effective capillary number and the static contact angle $\theta$. (Trojer et al., 2015). $\theta$ is defined as contact angle of the invaded (hydrophobic) fluid.

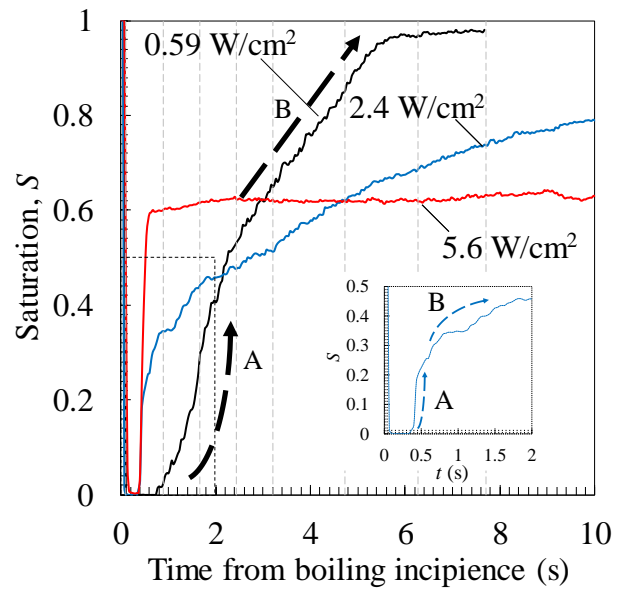

Fig. 10 Evolution of saturation at the contact surface between the case and wick. The inset shows enlargement of area surrounded with broken lines at $2.4 \mathrm{~W} / \mathrm{cm}^{2}$.

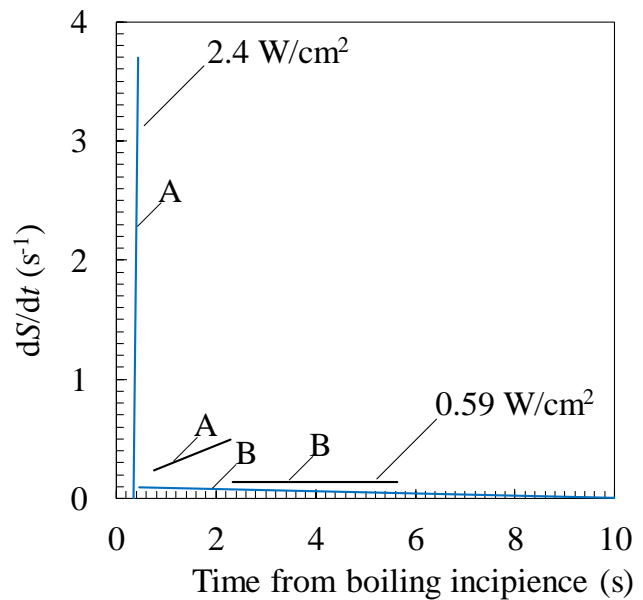

Fig. 11 Evolution of saturation rate at the contact surface between the case and wick.

\section{$4 \cdot 2$ 計算との比較}

シミュレーションと実験結果の比較を表 3 に示す．定常状態において接触面の一部が乾いている熱負荷 5.6 $\mathrm{W} / \mathrm{cm}^{2}$ と比較した. 蒸発器表面全体の平均温度と接触面の飽和度を示寸. また図 12 にはケースとウィックの接触 面における相分布を示す. シミュレーションは Throat 半径を図 4 の分布に基づいて試行ごとにウィック内にラン ダムに配置させているため，その影響で試行毎に結果が変化する．そのため今回は 6 回試行させた結果を示して

Table 3 Comparison of saturation at contact surface and evaporator temperature between experiment and simulation.

\begin{tabular}{lllr}
\hline \hline & & Saturation & Evaporator Temperature $\left({ }^{\circ} \mathrm{C}\right)$ \\
\hline \hline Exp. & & 0.63 & 114 \\
\hline Sim. & Ave. & 0.69 & 115 \\
\cline { 2 - 4 } & Run 1 & 0.58 & 115 \\
\cline { 2 - 4 } & Run 2 & 0.51 & 114 \\
\cline { 2 - 4 } & Run 3 & 0.61 & 115 \\
\cline { 2 - 4 } & Run 4 & 0.83 & 116 \\
\cline { 2 - 4 } & Run 5 & 0.70 & 115 \\
\cline { 2 - 4 } & Run 6 & 0.89 & 116 \\
\hline \hline
\end{tabular}


いる. 表 3 よりシミュレーションの平均と実験結果を比較すると蒸発器温度と飽和度ともに比較的良く一致して いる. シミュレーションの飽和度は, 試行毎にばらつきが大きいことが分かる. 図 12 の気相領域の分布も試行毎 にばらついている，核生成過熱度は試行毎にランダムに配置する Throat 半径に依存するため, 初期核生成位置が 試行毎に異なり，このような気相領域のばらつきにつながっている．計算では実際の現象と合わせて一度しか核 生成が起きないと仮定しており，核生成後は気液界面における圧力バランスの崩壊によってのみ界面が移動する ため, 気相領域が拡大しない限り液相領域が残存する. そのため計算結果は気相領域と液相領域が分かれて共存 する形となっている．また実験では蒸発器両端から蒸気管，CC へのヒートロスが原因で中央部が高温になって おり気相領域が中央部に存在していると考えられる。これは可視化のために金属管ではなく熱伝導率の低い石英 管を使用しているため, 通常より顕著になっていることが考えられる. 図 13 に Run 1 (図 12) の破線で示した断 面における温度分布および気液相界面形状を示す。 ウィックとグルーブとケースで構成される三相界線（TPCL） 付近に液相が残存していることが分かる. 図 12 の実験画像においても上端と下端，すなおち，三相界線付近に液 相が残存している様子が捉えられており, その残存挙動はシミュレーションで再現できている. しかし，シミュ レーションでは気相領域のかなりの部分はグルーブにつながっているのに対し，実験結果ではグルーブにつなが つていないように見える（図 12）。残存液相で気相領域が囲まれた分布になっている.シミュレーションではウ イックの気相領域内で発生した蒸気はウィックとグルーブの界面よりグルーブに抜けていくが，実験結果では少 なくとも接触面ではその抜け道がないということである. ある深さ（図 13 の y方向）においてグルーブに貫通し ている領域が存在していることが考えられるが本研究ではその特定はできなかった。また，撮影システムの空間 分解能不足によってその抜け道が撮影できていない可能性があるため，今後はよりミクロな観察を行う必要があ る.

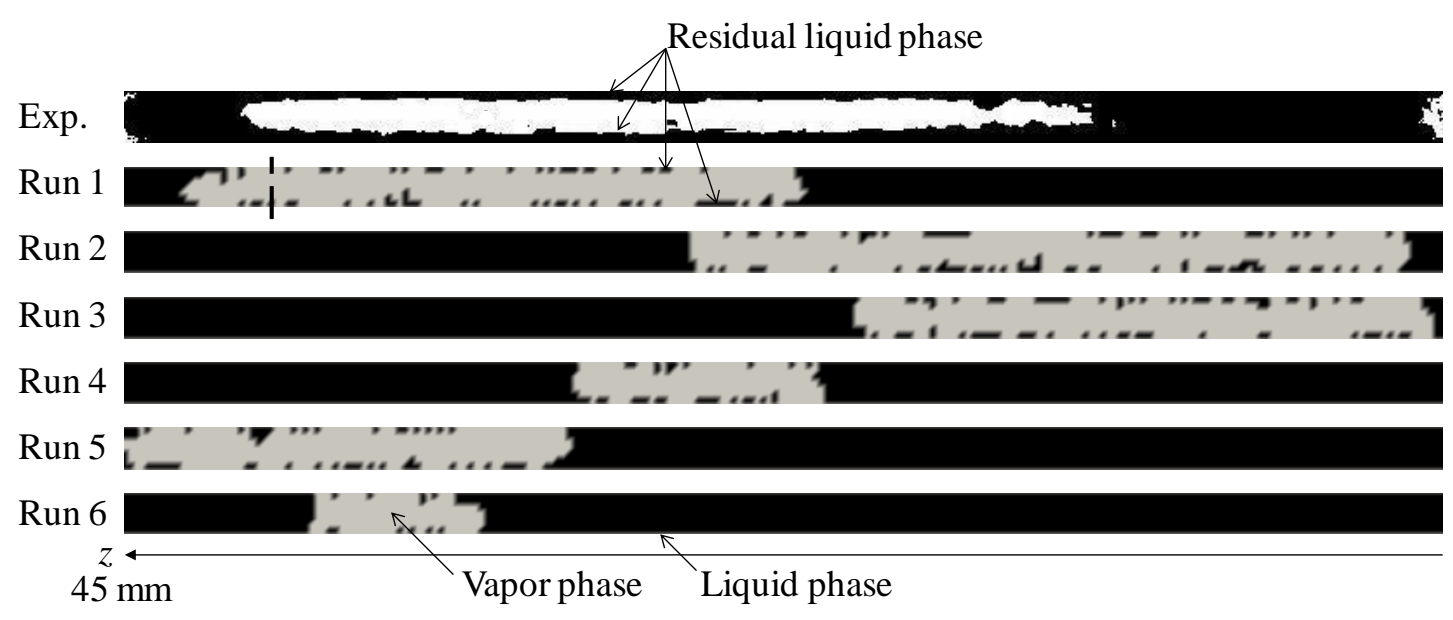

Fig. 12 Comparison of observed and simulated phase distribution at the contact surface between the wick and evaporator case in a steady-state. White is vapor phase and black is liquid phase. Top and bottom of images are three phase contact lines (TPCL) within the case, wick, and grooves.

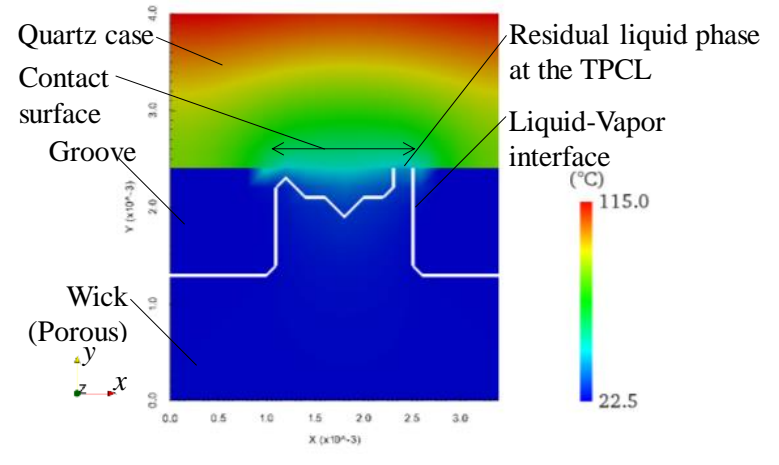

Fig. 13 Liquid-vapor interface shape and temperature distribution on the cross section shown by broken line at $z=40 \mathrm{~mm}$ of Run 1 in Fig. 12. Residual liquid phase is at the TPCL within the case, wick, and groove. 


\section{5. 結言}

本研究では LHP 可視化蒸発器の核沸騰起動における気液界面挙動および温度応答を熱流束 $0.59 \sim 5.6 \mathrm{~W} / \mathrm{cm}^{2}$ の範囲において調べた．熱流束が高くなるにつれ，核沸騰開始時間は短くなり，最大過熱度は大きくなった． 2.4 $\mathrm{W} / \mathrm{cm}^{2}$ 以下では核沸騰直後に蒸発器温度が急下降するオーバーシュートが見られたが, $5.6 \mathrm{~W} / \mathrm{cm}^{2}$ では核沸騰が起 きているにもかかわらずオーバーシュートが見られなかった．核沸騰起動においては，瞬間的にウイック表面全 体がドライアウトし，その後 CC 内の液が浸透していく挙動を観察した.

接触面における飽和度の時間応答より，熱流束 $0.59 \mathrm{~W} / \mathrm{cm}^{2}$ と $2.4 \mathrm{~W} / \mathrm{cm}^{2}$ においては，ある時間を境に吸水速度 が増加する領域と一定もしくは減少する領域が表れることが分かった。これは蒸発のない吸水挙動と蒸発を伴う 吸水挙動であると考えられる.

熱流束 $5.6 \mathrm{~W} / \mathrm{cm}^{2}$ においては，定常状態においても蒸発器ケースとウィックの接触面において一部が乾いてい ることが観察された. ポアネットワークによるシミュレーションにおいても接触面における気相領域を再現でき， ウィックとグルーブとケースで構成される三相界線に液相が残存する様子を捉えることができた．今後は，蒸発 器の熱流動現象をより詳細に理解するために，蒸発を伴う多孔体内非混合二相流，相置換に関する吸水挙動およ び排水挙動を明らかにしていく必要がある。

本研究費の一部は，マツダ財団の助成を受けた。 ここに感謝の意を表する.

\section{文献}

Alexander, Jr, E. G., Structure--property relationships in heat pipe wicking materials, Ph.D. Thesis, North Carolina State Univ. (1972).

Bruggeman, D. A. G., The prediction of the thermal conductivity of heterogeneous mixtures, Ann Phys, Vol. 2 (1935), pp.636-664.

Chi, S.W., Heat pipe theory and practice, 1st ed., McGraw-Hill (1976), p. 48.

Cieplak, M. and Robbins, M.O., Dynamical transition in quasistatic fluid invasion in porous media, Physical Review Letters, Vol. 60 (1988), pp.2042-2045.

Faghri, A., Heat pipe science and technology, 2nd. Ed., Global Digital Press (2016), p. 139.

Hatakenaka, R. and Okamoto, A., Visualization of internal fluid behavior in a miniature loop heat pipe using neutron radiography, Proceedings of 41st International Conference on Environmental Systems (2011), AIAA2011-5140.

Holtzman, R. and Segre, E., Wettability stabilizes fluid invasion into porous media via nonlocal, cooperative pore filling, Physical Review Letters, Vol. 115, 164501 (2015), pp.1-5.

日本熱物性学会, 新編熱物性ハンドブック, 養賢堂 (2008), p. 217.

Kaya, T., Ku, J., Hoang, T.T. and Cheung, M.K., Investigation of low power start-up characteristics of a loop heat pipe, American Institute of Physics Conference Proceedings, Vol. 458 (1999), pp. 799-804.

Krupiczka, R., Analysis of thermal conductivity in granular materials, International Chemical Engineering, Vol. 7 (1967), p. $122-$.

$\mathrm{Ku}$, J., Loop heat pipe start-up behaviors, Proceedings of 46th International Conference on Environmental Systems (2016), ICES-2016-24.

国井大蔵, 熱的単位操作 (上), 丸善 (1976).

Launay, S. and Mekni, N., Specifically designed loop heat pipe for quantitative characterisation, Proceedings of 15th International Heat Pipe Conference (2010).

Liao, Q. and Zhao, T.S., A visual study of phase-change heat transfer in a two-dimensional porous structure with a partial heating boundary, International Journal of Heat Mass Transfer, Vol. 43 (2000), pp.1089-1102.

Maidanik, Y., Solodovnik, N. and Fershtater, Y., Investigation of dynamic and stationary characteristics of a loop heat pipe, Proceedings of IX International Heat Pipe Conference (1995), pp.1002-1006.

Maxwell, J. C., A treatise on electricity and magnetism, Vol. 1. 3rd., Oxford Univ. Press (1954).

Mottet, L., Coquard, T. and Prat, M., Three dimensional liquid and vapour distribution in the wick of capillary evaporators, 
International Journal of Heat Mass Transfer, Vol. 83 (2015), pp.636-651.

西川原理仁, 長野方星, ポアネットワークモデルを用いたループヒートパイプ蒸発器の気液熱流動挙動の解析 (多 孔体内気液分布と熱伝達特性）, 日本伝熱学会論文集, Vol. 23 (2015), pp.71-80.

Nishikawara, M., Nagano, H., Mottet, L. and Prat, M., Formation of unsaturated regions in the porous wick of a capillary evaporator, International Journal of Heat and Mass Transfer, Vol. 89 (2015), pp.588-595.

Nishikawara, M., Otani, K., Ueda, Y. and Yanada, H., Fabrication and visualization of loop-heat-pipe evaporators using transparent tubes, Proceedings of Asian Conference on Thermal Science 2017 (2017), No. P00186.

Odagiri, K., Nishikawara, M. and Nagano, H., Microscale infrared observation of liquid-vapor interface behavior on the surface of porous media for loop heat pipes, Applied Thermal Engineering, Vol. 126 (2017), pp.1083-1090.

大島耕一, 松下正, 村上正秀, ヒートパイプ工学, 朝倉書店 (1979), p. 81.

Peterson, G.P. and Fletcher, L.S., Effective thermal conductivity of sintered heat pipe wicks, Journal of Thermophysics and Heat Transfer, Vol. 1 (1987), pp.343-347.

竹内雍, 多孔質体の性質とその応用技術, フジ・テクノシステム (1999), p. 395.

日本ヒートパイプ協会, 実用ヒートパイプ, 日刊工業新聞社 (1985), p. 28.

日本機械学会編, 伝熱工学(2014), p.131.

THERMAL-FLUIDS CENTRAL, Thermophysical properties: acetone, available from $<$ http://thermalfluidscentral.org/encyclopedia/index.php/Thermophysical_Properties:_Acetone>, (accessed on 10 November, 2017).

Trojer, M., Szulczewski, M. L. and Juanes, R., Stabilizing fluid-fluid displacements in porous media through wettability alteration, Physical Review Applied, Vol. 3, 054008 (2015), pp. 1-8.

$\mathrm{Xu}$, J., Zhang, L., Xu, H., Zhong, J. and Xuan, J., Experimental investigation and visual observation of loop heat pipes with two-layer composite wicks, International Journal of Heat Mass Transfer, Vol. 72 (2014), pp.378-387.

\section{References}

Alexander, Jr, E. G., Structure--property relationships in heat pipe wicking materials, Ph.D. Thesis, North Carolina State Univ. (1972).

Bruggeman, D. A. G., The prediction of the thermal conductivity of heterogeneous mixtures, Ann Phys, Vol. 2 (1935), pp.636-664.

Chi, S.W., Heat pipe theory and practice, 1st ed., McGraw-Hill (1976), p. 48.

Cieplak, M. and Robbins, M.O., Dynamical transition in quasistatic fluid invasion in porous media, Physical Review Letters, Vol. 60 (1988), pp.2042-2045.

Faghri, A., Heat pipe science and technology, 2nd. Ed., Global Digital Press (2016), p. 139.

Hatakenaka, R. and Okamoto, A., Visualization of internal fluid behavior in a miniature loop heat pipe using neutron radiography, in: 41st International Conference on Environmental Systems (2011), AIAA2011-5140.

Holtzman, R. and Segre, E., Wettability stabilizes fluid invasion into porous media via nonlocal, cooperative pore filling, Physical Review Letters, Vol. 115, 164501 (2015), pp.1-5.

Japan society of thermophysical properties, Thermophysical properties handbook, Yokendo (2008), p. 217 (in Japanese).

Kaya, T., Ku, J., Hoang, T.T. and Cheung, M.K., Investigation of low power start-up characteristics of a loop heat pipe, American Institute of Physics Conference Proceedings, Vol. 458 (1999), pp. 799-804.

Krupiczka, R., Analysis of thermal conductivity in granular materials, International Chemical Engineering, Vol. 7 (1967), p. $122-$.

Ku, J., Loop heat pipe start-up behaviors, Proceedings of 46th International Conference on Environmental Systems (2016), ICES-2016-24.

Kunii, T., Netsutekitanisousa (one), Maruzen (1976) (in Japanese).

Launay, S. and Mekni, N., Specifically designed loop heat pipe for quantitative characterisation, Proceedings of 15 th International Heat Pipe Conference (2010).

Liao, Q. and Zhao, T.S., A visual study of phase-change heat transfer in a two-dimensional porous structure with a partial heating boundary, International Journal of Heat Mass Transfer, Vol. 43 (2000), pp.1089-1102.

Maidanik, Y., Solodovnik, N. and Fershtater, Y., Investigation of dynamic and stationary characteristics of a loop heat pipe, Proceedings of IX International Heat Pipe Conference (1995), pp.1002-1006. 
Maxwell, J. C., A treatise on electricity and magnetism, Vol. 1. 3rd., Oxford Univ. Press (1954).

Mottet, L., Coquard, T. and Prat, M., Three dimensional liquid and vapour distribution in the wick of capillary evaporators, International Journal of Heat Mass Transfer, Vol. 83 (2015), pp.636-651.

Nishikawara, M. and Nagano, H., Numerical analysis of liquid-vapor thermo-fluid behavior in a loop heat pipe evaporator with pore network model (liquid-vapor phase distribution in a porous structure and heat-transfer characteristics), Thermal Science and Engineering, Vol. 23 (2015), pp.71-80 (in Japanese).

Nishikawara, M., Nagano, H., Mottet, L. and Prat, M., Formation of unsaturated regions in the porous wick of a capillary evaporator, International Journal of Heat and Mass Transfer, Vol. 89 (2015), pp.588-595.

Nishikawara, M., Otani, K., Ueda, Y. and Yanada, H., Fabrication and visualization of loop-heat-pipe evaporators using transparent tubes, Proceedings of Asian Conference on Thermal Science 2017 (2017), No. P00186.

Odagiri, K., Nishikawara, M. and Nagano, H., Microscale infrared observation of liquid-vapor interface behavior on the surface of porous media for loop heat pipes, Applied Thermal Engineering, Vol. 126 (2017), pp.1083-1090.

Oshima, K., Matsushita, T. and Murakami, M., Heat pipe kougaku, Asakura Publishing (1979), p. 81 (in Japanese).

Peterson, G.P. and Fletcher, L.S., Effective thermal conductivity of sintered heat pipe wicks, Journal of Thermophysics and Heat Transfer, Vol. 1 (1987), pp.343-347.

Takeuchi, Y., Porous materials - characterization, production and application -, Fuji technosystem (1999), p. 395 (in Japanese).

The Japan association for heat pipe, Jitsuyo heat pipe, Nikkan kogyo shimbun (1985), p. 28 (in Japanese).

The Japan Society of Mechanical Engineers ed., Heat transfer (2014), p.131, The Japan Society of Mechanical Engineers (in Japanese).

THERMAL-FLUIDS CENTRAL, Thermophysical properties: acetone, available from $<\mathrm{http}$ ://thermalfluidscentral.org/encyclopedia/index.php/Thermophysical_Properties:_Acetone> , (accessed on 10 November, 2017).

Trojer, M., Szulczewski, M. L. and Juanes, R., Stabilizing fluid-fluid displacements in porous media through wettability alteration, Physical Review Applied, Vol. 3, 054008 (2015), pp. 1-8.

Xu, J., Zhang, L., Xu, H., Zhong, J. and Xuan, J., Experimental investigation and visual observation of loop heat pipes with two-layer composite wicks, International Journal of Heat Mass Transfer, Vol. 72 (2014), pp.378-387. 